\title{
Effect of Metformin on Hepatocyte Insulin Receptor Binding in Normal, Streptozotocin Diabetic and Genetically Obese Diabetic (ob/ob) Mice
}

\author{
J. M. Lord, T. W.Atkins and C. J. Bailey \\ Department of Biological Sciences, University of Aston in Birmingham, Birmingham, UK
}

\begin{abstract}
Summary. The effect of metformin on hepatocyte insulin receptor binding was examined in normal, streptozotocin diabetic and genetically obese diabetic (ob/ob) mice. In normal mice, chronic administration of metformin $\left(60 \mathrm{mg} \cdot \mathrm{kg}^{-1}\right.$. day $^{-1}$ for 50 weeks) increased the number of low affinity receptors by $148 \%$. During acute studies, metformin increased $(30 \%)$ the number of low affinity receptors after $24 \mathrm{~h}$. When metformin was withdrawn after treatment for $96 \mathrm{~h}$, the number of low affinity receptors decreased, approaching control values by $48 \mathrm{~h}$. In severely insulin resistant $\mathrm{ob} / \mathrm{ob}$ mice, the concentrations of high and low affinity receptors were reduced by $60 \%$ and $27 \%$, respectively. A high dose of metfor$\min \left(240 \mathrm{mg} \cdot \mathrm{kg}^{-1} \cdot \mathrm{day}^{-1}\right.$ for 4 weeks) increased the concentration of high and low affinity receptors in ob/ob mice by
\end{abstract}

$63 \%$ and $86 \%$, respectively. However, the hypoglycaemic response to exogenous insulin was not altered. In streptozotocin-diabetic mice, the number of low affinity receptors was increased by $68 \%$ compared with normal mice. Metformin $\left(60 \mathrm{mg} \cdot \mathrm{kg}^{-1} \cdot \mathrm{day}^{-1}\right.$ for 10 weeks $)$ did not significantly alter the number of insulin receptors in streptozotocin-diabetic mice, but the hypoglycaemic response to exogenous insulin was improved by $94 \%$. The results raise the possibility that metformin might affect post-receptor sites of insulin action independently of effects at the receptor level.

Key words: Metformin, insulin receptor binding, hepatocytes, streptozotocin, ob/ob mice.

\section{Introduction}

Metformin reduces hyperglycaemia without elevation of plasma insulin in human non-insulin-dependent diabetes [1] and DBM mice [2]. Metformin also increases insulin mediated glucose uptake by diaphragm muscle of alloxan diabetic rats [3]. These observations suggest that metformin potentiates insulin action in diabetic states, inviting the study of a possible influence of metformin on insulin receptor binding. Recently, it has been reported that metformin increased insulin receptor binding in erythrocytes of normal subjects [4] and in IM-9 cultured lymphocytes and MCF-7 cultured breast cells [5]. The present study examines the effect of metformin on hepatocyte insulin receptor binding in two animal models of hyperglycaemia: the hypoinsulinaemic streptozotocin-diabetic mouse and the hyperinsulinaemic ob/ob mouse. The study determines the time and dose characteristics of the effects of metformin on insulin receptor binding.
Materials and Methods

\begin{abstract}
Animals
Male Theiller Original mice (Bantin \& Kingman, Hull, UK) and male genetically obese diabetic (ob/ob) mice and homozygous lean $(+/ t)$ mice from the Aston colony were used. The origin and characteristics of Aston ob/ob mice have been described elsewhere [6,7]. Mice were housed in an air-conditioned room at $22 \pm 2{ }^{\circ} \mathrm{C}$, and supplied a standard pellet diet (Mouse breeding diet, Heygate \& Sons, Northampton, UK) and tap water ad libitum.
\end{abstract}

\section{Chemicals}

Reagents of analytical grade and distilled water were used throughout. The chemicals and their sources were as follows: streptozotocin, $\mathrm{N}$-2-hydroxyethylpiperazine- $\mathrm{N}^{\prime}$-2-ethanesulphonic acid (HEPES), (N-tris(hydroxymethyl)methyl-2-aminoethanesulphonic acid)2-((2hydroxy-1, 1-bis(hydroxymethyl)-ethyl)aminoethanesulphonic acid) (TES), ethyleneglycol-bis-( $\beta$-aminoethyl ether)- $\mathrm{N}, \mathrm{N}, \mathrm{N}^{\prime}, \mathrm{N}^{\prime}$-tetracetic acid (EGTA), tricine, bacitracin and collagenase (batch C5138) from Sigma (London) Chemicals, Poole, UK; monocomponent porcine insulin (lot S8391272) from Novo Industria, Copenhagen, Den- 
mark; $\mathrm{Na}^{125} \mathrm{I}$ from Amersham International, Amersham, UK; insulin free bovine serum albumin (fraction V) (batch 318) from Miles Laboratories, Slough, UK; sodium pentobarbitone (Sagatal) from May \& Baker, Dagenham, UK; other reagents from British Drug Houses, Poole, UK. Pure metformin hydrochloride (batch 304) was supplied by Rona Laboratories, Hitchin, UK.

\section{Experimental Procedure}

Chronic Studies in Normal and Streptozotocin Diabetic Mice: Experiments were begun at $10-15$ weeks of age. Streptozotocin $(100 \mathrm{mg} / \mathrm{kg}$ in citrate buffer, pH 4.8) was administered by IP injection. After 2 weeks, mice were assigned to equi-hyperglycaemic groups (mean plasma glucose concentrations 16.9 and $17.3 \mathrm{mmol} / 1$ for control and test groups, respectively). Normal mice were treated with metformin $\left(60 \mathrm{mg} \cdot \mathrm{kg}^{-1} \cdot \mathrm{day}^{-1}\right)$ for 50 weeks, and streptozotocin diabetic mice were treated with the same dose of metformin for 10 weeks. The metformin was administered in the drinking water, and control mice received ordinary drinking water. The dose of metformin $(60 \mathrm{mg}$. $\mathrm{kg}^{-1} \cdot$ day $^{-1}$ ) corresponds with the manufacturer's maximum recommended clinical dose on a weight for weight basis. Fluid intake was monitored, and the concentration of the drug was adjusted according$1 y$, as described elsewhere [8]. The procedure involves daily measurement of drinking fluid intake using a graduated drinking dispenser with a spill-collector. The concentration of the drug in the drinking fluid is adjusted on a daily basis in short-term studies and on a weekly basis in long-term studies to provide the required weight-related dose of the drug.

Acute Studies in Normal Mice: To examine the time dependency of the effect of metformin, groups of 20-week-old normal mice received metformin $\left(60 \mathrm{mg} \cdot \mathrm{kg}^{-1} \cdot\right.$ day $\left.^{-1}\right)$ in the drinking water for $24,48,72$ and $96 \mathrm{~h}$. The effect of metformin withdrawal was examined in groups of 20-week-old normal mice after treatment with metformin $(60 \mathrm{mg}$. $\mathrm{kg}^{-1} \cdot \mathrm{day}^{-1}$ ) for $96 \mathrm{~h}$. Tests were performed 24 and $48 \mathrm{~h}$ after the drug was withdrawn.

Studies in $o b / o b$ Mice: The effect of metformin $(120$ and $240 \mathrm{mg}$. $\mathrm{kg}^{-1}$. day ${ }^{-1}$ for 4 weeks) administered in the drinking water was examined in 20-week-old ob/ob mice. Untreated ob/ob mice were compared with untreated age-matched homozygous lean $(+/+)$ mice.

\section{Insulin Binding Studies}

Blood samples $(30 \mu)$ were obtained from the cut tip of the tail of fed mice at $10.00 \mathrm{~h}$ on the day of the insulin binding study. Plasma was separated and assayed for glucose [9]. In some studies, plasma insulin [10] and plasma metformin [11] were also measured. Mice were anaesthetised with sodium pentobarbitone $(50 \mathrm{mg} / \mathrm{kg})$ by IP injection, and hepatocytes were isolated by a modification of the method of Kahn et al. [12]. The liver was perfused in situ at $6 \mathrm{ml} / \mathrm{min}$ with a $\mathrm{Ca}^{++}$free HEPES buffer containing EGTA $(1.28 \mathrm{mmol} / 1)$ and sodium heparin (160 U/1) for 3-4 min, followed by $\mathrm{Ca}^{++}$free HEPES buffer alone for 3-4 min, followed by HEPES buffer containing $\mathrm{Ca}^{++}(425 \mathrm{mmol} / 1)$ and collagenase $(500 \mathrm{mg} / \mathrm{l})$ for $4-5 \mathrm{~min}$, until the liver was approximately twice its original size. The liver was removed, rinsed in HEPES buffer number 4 [13] and disintegrated by gentle manual agitation. The cell suspension was filtered through a $125 \mu$ nylon mesh filter (Sericol, Birmingham, UK) and centrifuged at $10 \mathrm{~g}$ for $5 \mathrm{~min}$ at room temperature. The cells were washed and centrifuged twice, and filtered through a $60 \mu$ nylon mesh filter. Cell viability, assessed by trypan blue exclusion for 2 min was always $>75 \%$. Hepatocyte number and diameter were determined using a Neubauer haemocytometer (Phillip Harris Biological, Oldmixon, UK) and cell number was adjusted to $2.0 \times 10^{6}$ cells $/ \mathrm{ml}$.

Isolated hepatocytes were incubated at $22^{\circ} \mathrm{C}$ in HEPES buffer number 4 ( $\mathrm{pH} 7.8$ ) containing $1 \%$ bovine serum albumin, $0.5-500 \mathrm{ng} /$ $500 \mu \mathrm{l}$ monocomponent porcine insulin, $800 \mathrm{mg} / \mathrm{l}$ bacitracin to reduce insulin degradation [14], and $0.2 \mathrm{ng} / 500 \mu \mathrm{l}^{125} \mathrm{I}$-monoiodinated por- cine insulin, in a final volume of $500 \mu \mathrm{l}$. The labelled insulin was prepared by the Chloramine $\mathrm{T}$ method [15] to a specific activity of $215-230 \mu \mathrm{Ci} / \mu \mathrm{g}$. All incubations were performed in triplicate in $1.5 \mathrm{ml}$ capacity polyethylene microfuge tubes (PPR15, Beckman Riic, High Wycombe, UK). Incubations were terminated after $120 \mathrm{~min}$ by addition of $1.0 \mathrm{ml}$ of ice-cold HEPES buffer and the tubes were centrifuged at $9000 \mathrm{~g}$ for 1 min in a Beckman microfuge (type B, Beckman Riic). The pellet was washed once with ice-cold HEPES buffer, and the tip of the tube was excised and counted in a gamma spectrometer. Results were corrected for non-specific binding by subtracting the amount of radioactivity bound in the presence of excess porcine insulin $(50 \mu \mathrm{g} /$ tube) [15]. Non-specific binding was $4.4 \pm 0.5 \%$ (mean \pm SEM) of the total binding to hepatocytes.

Data were analysed using a Scatchard plot [16] to determine the number of receptors. The Scatchard plot for hepatocyte insulin receptor binding is curvilinear. It is not established whether this represents two or more classes of receptors with different but fixed affinities, or one class of receptors exhibiting negatively cooperative site-site interactions [17]. The present data were interpreted by computer-assisted analysis (ICL 1904S, International Computers, London, UK), using a model which assumes two classes of receptors, one with a high affinity and one with a low affinity [18]. The apparent receptor affinity was taken as the concentration of native insulin required to reduce by $50 \%$ the specific cell bound fraction of ${ }^{125} \mathrm{I}$-insulin [19].

\section{Insulin Hypoglycaemia Tests}

Insulin hypoglycaemia tests were performed at $10.00 \mathrm{~h}$ in fed streptozotocin-diabetic and ob/ob mice 1 week before the insulin binding study. Blood samples $(20 \mu 1)$ were obtained from the cut tip of the tail immediately before, and at 15, 30,60 and 90 min after an IP injection of monocomponent porcine insulin $10.15 \mathrm{U} / \mathrm{kg}$ in streptozotocin-diabetic mice and $100 \mathrm{U} / \mathrm{kg}$ in ob/ob mice). Plasma was separated and assayed for glucose [9].

\section{Statistical Analysis}

Student's t-test was used for statistical comparisons. Differences were considered to be significant if $p<0.05$.

\section{Results}

\section{Chronic Studies in Normal Mice}

Table 1 shows body weights, plasma glucose and insulin concentrations and hepatocyte insulin receptor status in normal mice treated with metformin $\left(60 \mathrm{mg} \cdot \mathrm{kg}^{-1}\right.$. day $^{-1}$ ) for 50 weeks. Metformin did not alter body weight or plasma insulin concentrations significantly, although a small increase in plasma glucose concentrations was observed, as previously reported [8]. The total number of hepatocyte insulin receptors was increased twofold by the metformin treatment and was due to an increase in the number of low affinity receptors. There was no significant effect on the number of high affinity receptors, or the apparent affinity constant.

\section{Acute Studies in Normal Mice}

Normal mice treated with metformin $\left(60 \mathrm{mg} \cdot \mathrm{kg}^{-1}\right.$. day ${ }^{-1}$ ) showed an increase in the number of low affinity hepatocyte insulin receptors after $24 \mathrm{~h}$ (Table 2). The effect was similar up to $96 \mathrm{~h}$. There was no significant al- 
Table 1. Chronic effect of metformin $\left(60 \mathrm{mg} \cdot \mathrm{kg}^{-1} \cdot\right.$ day ${ }^{-1}$ for 50 weeks $)$ on hepatocyte insulin receptor status in normal mice

\begin{tabular}{llllllll}
\hline Mice & $\begin{array}{l}\text { Body } \\
\text { weight } \\
(\mathrm{g})\end{array}$ & $\begin{array}{l}\text { Plasma } \\
\text { glucose } \\
(\mathrm{mmol} / \mathrm{l})\end{array}$ & $\begin{array}{l}\text { Plasma } \\
\text { insulin } \\
(\mathrm{ng} / \mathrm{ml})\end{array}$ & $\begin{array}{l}\text { Total receptor } \\
\text { number } \\
\left(\text { per cell } \times 10^{5}\right)\end{array}$ & $\begin{array}{l}\text { High affinity } \\
\text { receptor number } \\
\left(\text { per cell } \times 10^{5}\right)\end{array}$ & $\begin{array}{l}\text { Low affinity } \\
\text { receptor number } \\
\left(\text { per cell } \times 10^{5}\right)\end{array}$ & $\begin{array}{l}\text { Apparent receptor } \\
\text { affinity constant } \\
(\mathrm{nmol} / 1)\end{array}$ \\
\hline Control & $46.0 \pm 0.5$ & $7.4 \pm 0.3$ & $2.94 \pm 0.59$ & $2.88 \pm 0.30$ & $1.25 \pm 0.19$ & $1.61 \pm 0.40$ & $1.65 \pm 0.26$ \\
Metformin & $49.2 \pm 2.3$ & $10.0 \pm 0.4^{\mathrm{a}}$ & $3.34 \pm 0.61$ & $5.29 \pm 0.41^{\mathrm{b}}$ & $1.19 \pm 0.06$ & $4.00 \pm 0.41^{\mathrm{b}}$ & $2.13 \pm 0.27$ \\
\hline
\end{tabular}

Results are expressed as mean \pm SEM of four mice

${ }^{a} p<0.01$

b $p<0.02$ compared with control group

Table 2. Acute time-dependent effect of metformin $\left(60 \mathrm{mg} \cdot \mathrm{kg}^{-1} \cdot \mathrm{day}^{-1}\right)$ and the effect of its withdrawal after $96 \mathrm{~h}$ on hepatocyte insulin receptor status in normal mice

\begin{tabular}{llllll}
\hline Mice & $\begin{array}{l}\text { Plasma } \\
\text { metformin } \\
(\mu \mathrm{g} / \mathrm{ml})^{\mathrm{a}}\end{array}$ & $\begin{array}{l}\text { Total receptor } \\
\text { number } \\
\left(\text { per cell } \times 10^{5}\right)\end{array}$ & $\begin{array}{l}\text { High affinity } \\
\text { receptor number } \\
\left(\text { per cell } \times 10^{5}\right)\end{array}$ & $\begin{array}{l}\text { Low affinity } \\
\text { receptor number } \\
\left(\text { per cell } \times 10^{5}\right)\end{array}$ & $\begin{array}{l}\text { Apparent affinity } \\
\text { receptor constant } \\
(\mathrm{nmol} / 1)\end{array}$ \\
\hline Control & $\mathrm{ND}$ & $3.58 \pm 0.23$ & $1.07 \pm 0.10$ & $2.50 \pm 0.05$ & $2.06 \pm 0.10$ \\
Metformin 24h & 0.41 & $4.40 \pm 0.38$ & $1.15 \pm 0.10$ & $3.24 \pm 0.32^{\mathrm{b}}$ & $1.95 \pm 0.20$ \\
Metformin 48 h & 0.22 & $4.68 \pm 0.19^{\mathrm{b}}$ & $1.54 \pm 0.21$ & $3.14 \pm 0.09^{\mathrm{b}}$ & $1.94 \pm 0.13$ \\
Metformin 72 $\mathrm{h}$ & 0.23 & $4.56 \pm 0.18^{\mathrm{b}}$ & $1.29 \pm 0.17$ & $3.26 \pm 0.22^{\mathrm{b}}$ & $1.89 \pm 0.06$ \\
Metformin 96h & 0.34 & $5.97 \pm 0.76^{\mathrm{b}}$ & $1.39 \pm 0.13$ & $4.58 \pm 0.73^{\mathrm{b}}$ & $1.83 \pm 0.07$ \\
Metformin withdrawn 24h & $\mathrm{ND}$ & $6.00 \pm 0.88^{\mathrm{b}}$ & $1.51 \pm 0.20$ & $4.33 \pm 0.95$ & $2.04 \pm 0.11$ \\
Metformin withdrawn 48 h & ND & $4.42 \pm 0.42$ & $1.30 \pm 0.13$ & $3.11 \pm 0.38$ & $1.84 \pm 0.08$ \\
\hline
\end{tabular}

Results are expressed as mean \pm SEM of four mice

analysis performed on pooled $50 \mu 1$ samples from four mice

${ }^{b} p<0.05$ compared with control group

$\mathrm{ND}=$ not detectable

Table 3. Chronic effect of metformin (120 and $240 \mathrm{mg} \cdot \mathrm{kg}^{-1} \cdot$ day ${ }^{-1}$ for 4 weeks) on hepatocyte insulin receptor status in obese diabetic (ob/ob) mice

\begin{tabular}{|c|c|c|c|c|c|c|c|c|}
\hline Mice & Body weight & $\begin{array}{l}\begin{array}{l}\text { Plasma } \\
\text { glucose }\end{array} \\
(\mathrm{mmol} / 1)\end{array}$ & $\begin{array}{l}\text { Plasma } \\
\text { insulin } \\
(\mathrm{ng} / \mathrm{ml})\end{array}$ & $\begin{array}{l}\text { Total receptor } \\
\text { number } \\
\left(\text { per cell } \times 10^{5}\right)\end{array}$ & $\begin{array}{l}\text { Total receptor } \\
\text { concentration }\end{array}$ & $\begin{array}{l}\text { High affinity } \\
\text { receptor } \\
\text { concentration } \\
\text { (per } \mu \mathrm{m}^{2} \text { cell } \\
\text { surface area) }\end{array}$ & $\begin{array}{l}\text { Low affinity } \\
\text { receptor } \\
\text { concentration } \\
\text { (per } \mu \mathrm{m}^{2} \text { cell } \\
\text { surface area) }\end{array}$ & $\begin{array}{l}\text { Apparent } \\
\text { receptor } \\
\text { affinity } \\
\text { constant } \\
(\mathrm{nmol} / \mathrm{l})\end{array}$ \\
\hline $\begin{array}{l}\text { Lean }(+/ t) \\
\text { control }\end{array}$ & $40.5 \pm 1.1^{b}$ & $7.3 \pm 0.4^{\mathrm{a}}$ & $2.1 \pm 0.3^{b}$ & $3.58 \pm 0.23$ & $168 \pm 9^{b}$ & $48 \pm 5^{b}$ & $120 \pm 2^{b}$ & $2.06 \pm 0.10$ \\
\hline $\begin{array}{l}\text { Obese }(\mathrm{ob} / \mathrm{ob}) \\
\text { metformin } \\
\left(120 \mathrm{mg} \cdot \mathrm{kg}^{-1}\right. \\
\left.\text { day }^{-1}\right)\end{array}$ & $96.0 \pm 5.8$ & $12.5 \pm 0.8$ & $36.6 \pm 2.5$ & $4.42 \pm 0.26$ & $137 \pm 6$ & $25 \pm 3$ & $103 \pm 12$ & $1.85 \pm 0.15$ \\
\hline
\end{tabular}

Results are expressed as mean \pm SEM of four mice

${ }^{\text {a }} p<0.05$

${ }^{\mathrm{b}} p<0.01$ compared with obese control group

teration in the number of high affinity receptors or the apparent affinity constant. When metformin was withdrawn after treatment at a dose of $60 \mathrm{mg} \cdot \mathrm{kg}^{-1} \cdot \mathrm{day}^{-1}$ for $96 \mathrm{~h}$, the total number of hepatocyte insulin receptors was still raised after $24 \mathrm{~h}$, but values were reduced, approaching control values after $48 \mathrm{~h}$.

\section{Studies in $o b / o b$ Mice}

As described elsewhere [7], the ob/ob mice showed gross obesity, moderate hyperglycaemia and severe hyperinsulinaemia (Table 3). The total number of insulin receptors per cell was similar in control lean and ob/ob 
Table 4. Chronic effect of metformin (120 and $240 \mathrm{mg} \cdot \mathrm{kg}^{-1} \cdot \mathrm{day}^{-1}$ for 3 weeks) on the hypoglycaemic response to insulin $(100 \mathrm{U} / \mathrm{kg}, \mathrm{IP})$ in obese diabetic $(\mathrm{ob} / \mathrm{ob})$ mice

\begin{tabular}{llll}
\hline Mice & \multicolumn{3}{c}{ Plasma glucose (percentage decrease) } \\
\cline { 2 - 4 } & $\% \Delta 15 \mathrm{~min}$ & $\% \Delta 30 \mathrm{~min}$ & $\% \Delta 60 \mathrm{~min}$ \\
\hline Obese $(\mathrm{ob} / \mathrm{ob})$ control & $-21.7 \pm 0.4$ & $-29.5 \pm 0.7$ & $-33.9 \pm 2.2$ \\
Obese $(\mathrm{ob} / \mathrm{ob})$ & $-18.1 \pm 1.6$ & $-27.8 \pm 1.5$ & $-27.2 \pm 2.6$ \\
metformin & & & \\
$\left(120 \mathrm{mg} \cdot \mathrm{kg}^{-1} \cdot \mathrm{day}^{-1}\right)$ & & & \\
Obese $(\mathrm{ob} / \mathrm{ob})$ & $-19.3 \pm 2.4$ & $-23.8 \pm 4.0$ & $-35.9 \pm 4.0$ \\
metformin & & & \\
$\left(240 \mathrm{mg} \cdot \mathrm{kg}^{-1} \cdot \mathrm{day}^{-1}\right)$ & & & \\
\hline
\end{tabular}

Results are expressed as mean $\pm \mathrm{SEM}$ of four mice

$\% \Delta$ is the percentage change in the plasma glucose concentration compared with time zero

mice. However, as noted previously [12] the size of hepatocytes was greater in ob/ob mice. The diameters were $26 \pm 1$ and $32 \pm 2 \mu \mathrm{m}$ (mean $\pm \mathrm{SEM}, p<0.05$ ) in lean and ob/ob mice, respectively. Thus the concentration of receptors in $\mathrm{ob} / \mathrm{ob}$ mice was substantially reduced when expressed per unit surface area of plasma membrane. This was attributable to a decrease in the concentration of both high (60\% decrease) and low (27\% decrease) affinity receptors. There was no change in the apparent affinity constant.

Treatment with metformin (120 and $240 \mathrm{mg} \cdot \mathrm{kg}^{-1}$. day $^{-1}$ for 4 weeks) did not alter body weight or plasma glucose concentrations significantly. However, the larger dose of metformin reduced plasma insulin concentrations. This reduction was accompanied by an increase in the total concentration of insulin receptors, due largely to an increase in the low affinity receptors. Treatment with metformin did not alter the apparent affinity constant.

Insulin hypoglycaemia tests in ob/ob mice revealed no significant changes in the hypoglycaemic response to exogenous insulin $(100 \mathrm{U} / \mathrm{kg})$ after metformin treatment (Table 4). However, it must be noted that these in vivo tests may not discriminate small changes in insulin action in mice with such pronounced insulin resistance [20].

\section{Chronic Studies in Streptozotocin-Diabetic Mice}

Streptozotocin-diabetic mice displayed hyperglycaemia without significant weight loss (Table 5). The total number of hepatocyte insulin receptors was increased compared with age-matched normal mice and was accounted for mainly by an increase in the number of low affinity receptors. Similar observations have been made using several cell types in streptozotocin-diabetic rats [21-26]. In the present study, there was a small decrease in the apparent affinity constant of insulin binding to hepatocytes of streptozotocin-diabetic mice. Treatment with metformin $\left(60 \mathrm{mg} \cdot \mathrm{kg}^{-1} \cdot \mathrm{day}^{-1}\right)$ for 10 weeks did not significantly alter body weight, plasma glucose concentrations or hepatocyte insulin receptor status. However, insulin hypoglycaemia tests showed a greater hypoglycaemic response to exogenous insulin $(0.15 \mathrm{U} /$ $\mathrm{kg}$ ) in metformin-treated-streptozotocin-diabetic mice (Table 6).

Table 5. Chronic effect of metformin $\left(60 \mathrm{mg} \cdot \mathrm{kg}^{-1} \cdot\right.$ day $^{-1}$ for 10 weeks) on hepatocyte insulin receptor status in streptozotocin-diabetic mice

\begin{tabular}{|c|c|c|c|c|c|c|}
\hline Mice & $\begin{array}{l}\text { Body weight } \\
\text { (g) }\end{array}$ & $\begin{array}{l}\begin{array}{l}\text { Plasma } \\
\text { glucose }\end{array} \\
(\mathrm{mmol} / 1)\end{array}$ & $\begin{array}{l}\text { Total receptor } \\
\text { number } \\
\left(\text { per cell } \times 10^{5}\right)\end{array}$ & $\begin{array}{l}\text { High affinity } \\
\text { receptor } \\
\text { number } \\
\left(\text { per cell } \times 10^{5} \text { ) }\right.\end{array}$ & $\begin{array}{l}\text { Low affinity } \\
\text { receptor } \\
\text { number } \\
\left(\text { per cell } \times 10^{5}\right)\end{array}$ & $\begin{array}{l}\text { Apparent re- } \\
\text { ceptor affinity } \\
\text { constant } \\
(\mathrm{nmol} / \mathrm{l})\end{array}$ \\
\hline Normal age-matched & $42.3 \pm 1.9$ & $7.0 \pm 0.3$ & $3.5 \pm 0.2$ & $1.07 \pm 0.18$ & $2.50 \pm 0.05$ & $2.06 \pm 0.10$ \\
\hline $\begin{array}{l}\text { Streptozotocin } \\
\text { (control) }\end{array}$ & $39.9 \pm 2.1$ & $20.2 \pm 3.5^{\mathrm{a}}$ & $6.0 \pm 0.3^{a}$ & $1.77 \pm 0.62$ & $4.21 \pm 0.38^{\mathrm{a}}$ & $1.51 \pm 0.14^{\mathrm{a}}$ \\
\hline
\end{tabular}

Results are expressed as mean \pm SEM of five mice

a $p<0.05$ compared with normal age-matched mice

Table 6. Chronic effect of metformin $\left(60 \mathrm{mg} \cdot \mathrm{kg}^{-1} \cdot \mathrm{day}^{-1}\right.$ for 9 weeks $)$ on the hypoglycaemic response to insulin $(0.15 \mathrm{U} / \mathrm{kg}$, IP) in streptozotocin-diabetic mice

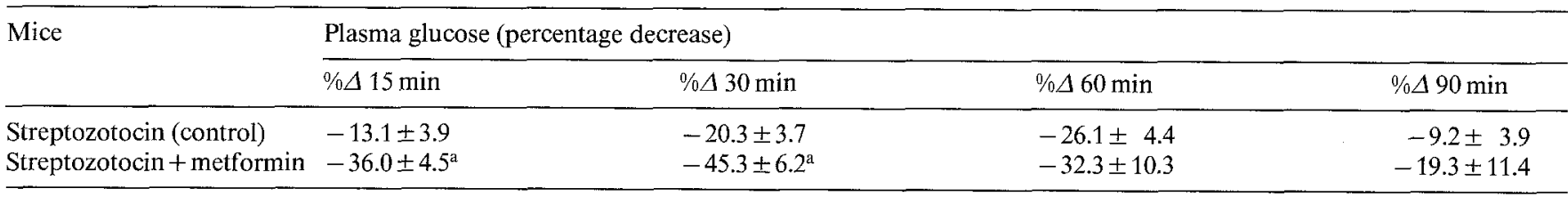

Results are expressed as mean $\pm \mathrm{SEM}$ of five mice

$\% \Delta$ is the percentage change in the plasma glucose concentration compared with time zero

${ }^{a} p<0.01$ compared with control group 


\section{Discussion}

The results demonstrate a rapid (within $24 \mathrm{~h}$ ) and sustained (up to 50 weeks) increase in the number of low affinity hepatocyte insulin receptors during treatment with metformin $\left(60 \mathrm{mg} \cdot \mathrm{kg}^{-1} \cdot\right.$ day $\left.^{-1}\right)$ in normal mice. This increase corresponds with the effect of metformin on insulin receptors in erythrocytes of non-diabetic and non-insulin dependent diabetic patients [4, 27]. Metformin did not produce a hypoglycaemic effect in normal mice, confirming previous observations in non-diabetic animals and man $[1,8,28]$.

In ob/ob mice, a very high dose of metformin ( $240 \mathrm{mg} \cdot \mathrm{kg}^{-1} \cdot \mathrm{day}^{-1}$ for 4 weeks) increased the concentrations of high and low affinity receptors. This effect was accompanied by a small decrease in plasma insulin concentrations, but no significant change in glycaemia. Although this suggests a slight improvement of insulin resistance, insulin hypoglycaemia tests were not altered significantly. A post-receptor defect of insulin action has been noted in ob/ob mice $[29,30]$. The present study suggests that this is not corrected by metformin treatment.

Streptozotocin diabetes is associated with hypoinsulinaemia [26], and the increased number of insulin receptors in streptozotocin-diabetic mice may reflect the lifting of a down regulation effect exerted by normal insulin concentrations [17]. At the dose used $(60 \mathrm{mg}$. $\mathrm{kg}^{-1} \cdot$ day $^{-1}$ ), metformin did not increase the number of hepatocyte insulin receptors significantly in streptozotocin-diabetic mice. However, the number of receptors in these mice was similar to that observed after chronic metformin treatment in normal mice. It is tempting to speculate that this may represent an upper limit for the number of hepatocyte insulin receptors.

Despite no significant effect of metformin on hepatocyte insulin receptor status in streptozotocin-diabetic mice, metformin improved the hypoglycaemic response to exogenous insulin in these mice. Since there is evidence for a post-receptor defect of insulin action in streptozotocin diabetes [26], the present study suggests that this defect is different from the post-receptor defect in ob/ob mice. Metformin improved the hypoglycaemic action of insulin without alteration of hepatocyte receptor status in streptozotocin-diabetic mice. In ob/ob mice metformin produced a substantial increase in hepatocyte receptor number but an effect on insulin action was equivocal. However, the receptor data refer only to hepatocytes, and it is not established whether all insulin target tissues manifest the same defects of receptor and post-receptor status, or respond to insulin in the same manner [31].

The mechanisms responsible for the metformin-induced increase in the number of low affinity hepatocyte insulin receptors in normal and ob/ob mice are not established. However, studies in vitro indicate that metformin can act directly on the target cells without a requirement for de novo protein synthesis $[4,5]$. The poor correlation between changes in hepatocyte insulin receptor status and the hypoglycaemic action of insulin during metformin treatment, suggests that metformin might influence post-receptor sites of insulin action independently of effects on insulin receptor binding.

Acknowledgements. We thank Professor H.F. Woods and Ms. C. A. Casey, Hallamshire Hospital, Sheffield for the determination of plasma metformin, and Rona Laboratories Ltd. Hitchen for their support.

\section{References}

1. Herman LS (1979) Metformin: a review of its pharmacological properties and therapeutic use. Diabete Metab 5: 233-245

2. Junien JL, Brohon J, Guillaume M, Sterne J (1979) DBM mice as a pharmocological model of maturity onset diabetes. Studies with metformin. Arch Int Pharmacodyn 241: 165-176

3. Frayn KN, Adnitt PI (1972) Effect of metformin on glucose uptake by isolated diaphragm from normal and diabetic rats. Biochem Pharmacol 21:3153-3162

4. Holle A, Mangels W, Dreyer M, Kuhanu J, Rudiger HW (1981) Biguanide treatment increases the number of insulin-receptor sites on human erythrocytes. N Engl J Med 305: 563-566

5. Vigneri R, Pezzino V, Wong KY, Goldfine ID (1982) Comparison of the in vitro effect of biguanides and sulfonylureas on insulin binding to its receptors in target cells. J Clin Endocrinol Metab 54: 95-101

6. Flatt PR, Bailey CJ (1981) Abnormal plasma glucose and insulin responses in heterozygous lean $(\mathrm{ob} /+)$ mice. Diabetologia 20 : $573-577$

7. Bailey CJ, Flatt PR, Atkins TW (1982) Influence of genetic background and age on the expression of the obese hyperglycaemic syndrome in Aston ob/ob mice. Int J Obesity 6:11-21

8. Billingham MS, Hall RA, Simpson S, Bailey CJ (1981) Plasma high density lipoprotein cholesterol in streptozotocin diabetic and non-diabetic mice after prolonged administration of glibenclamide, chlorpropamide and metformin. Diabete Metab 7:271-274

9. Stevens JF (1971) Determination of glucose by an automatic analyser. Clin Chim Acta 32: 199-201

10. Bailey CJ, Ahmed-Sorour H (1980) Role of ovarian hormones in the long-term control of glucose homeostasis: effects on insulin secretion. Diabetologia 19: 475-481

11. Lennard MS, Casey C, Tucker GT, Woods HF (1978) Determination of metformin in biological samples. Br J Clin Pharmacol 6: $183-185$

12. Kahn CR, Neville DM, Roth J (1973) Insulin-receptor interaction in the obese-hyperglycemic mouse. A model of insulin resistance. J Biol Chem 248: 244-250

13. Seglen PO (1972) Preparation of rat liver cells. Exp Cell Res 74: $450-454$

14. Roth RA (1981) Bacitracin: an inhibitor of the insulin degrading activity of glutathione-insulin transhydrogenase. Biochem Biophys Res Comm 98: 431-438

15. Freychet $\mathbf{P}$, Roth J, Neville DM (1971) Insulin receptors in the liver: specific binding of $\left.{ }^{125} \mathrm{I}\right)$ insulin to the plasma membrane and its relation to insulin bioactivity. Proc Natl Acad Sci USA 68: 1833-1837

16. Scatchard G (1949) The attractions of proteins for small molecules and ions. Ann NY Acad Sci 51: 660-672

17. Bailey CJ, Lord JM, Atkins TW (1983) The insulin receptor and diabetes. In: Santiago J, Nattrass M (eds) Recent advances in diabetes. Churchill Livingstone, Edinburgh (in press)

18. Kahn CR (1975) Membrane receptors for polypeptide hormones. In: Konn ED (ed) Methods in membrane biology, Vol3. Plenum Press, New York, pp 81-146

19. Beck-Nielsen H, Pedersen O, Lindskov HO (1979) Increased insu- 
lin sensitivity and cellular insulin binding in obese diabetics following treatment with glibenclamide. Acta Endocrinol (Copenh) 90: 451-462

20. Flatt PR, Bailey CJ (1981) Development of glucose intolerance and impaired plasma insulin response to glucose in obese hyperglycaemic (ob/ob) mice. Horm Metab Res 13: 556-560

21. Davidson MB, Kaplan SA (1977) Increased insulin binding by hepatic plasma membranes from diabetic rats. Normalization by insulin therapy. J Clin Invest 59: 22-30

22. Schoenic E, Zapf J, Froesch ER (1977) Effect of insulin and NSILA on adipocytes of normal and diabetic rats: receptor binding, glucose transport and glucose metabolism. Diabetologia 13: 243-249

23. Kasuga M, Akanuma Y, Iwamoto Y, Kosaka K (1978) Insulin binding and glucose metabolism in adipocytes of streptozotocindiabetic rats. Am J Physiol 235: E175-E182

24. Wieringa T, Krans HMJ (1978) Reduced glucose transport and increased binding of insulin in adipocytes from diabetic and fasted rats. Biochim Biophys Acta 538: 563-570

25. Duckworth WC, Gifford D, Kitabchi AE, Runyan K, Solomon SS (1979) Insulin binding and degradation by muscles from streptozotocin-diabetic rats. Diabetes 28: 746-748

26. Kobayashi M, Olefsky JM (1979) Effects of streptozotocin-induced diabetes on insulin binding, glucose transport, and intracellular glucose metabolism in isolated rat adipocytes. Diabetes 28 : $87-95$
27. Lord JM, White SI, Bailey CJ, Atkins TW, Fletcher RF, Taylor $\mathrm{KG}$ (1983) Effect of metformin on insulin receptor binding and glycaemic control in Type 2 diabetes. Br Med J 286: 830-831

28. Bailey CJ, Broadbent ME (1981) Chronic effects of glibenclamide, chlorpropamide and metformin on plasma glucose and insulin in non-diabetic rats. Gen Pharmacol 12: 323-326

29. Le Marchand-Brustel Y, Jeanrenaud B, Freychet P (1978) Insulin binding and effects of isolated soleus muscle of lean and obese mice. Am J Physiol 234: E348-E358

30. Grundleger ML, Godbole VY, Thenen SW (1980) Age-dependent development of insulin resistance of soleus muscle in genetically obese (ob/ob) mice. Am J Physiol 239: E363-E371

31. Kolterman OG, Gray RS, Griffin J, Burstein P, Insel J, Scarlett JA, Olefsky JM (1981) Receptor and post-receptor defects contribute to the insulin resistance in non-insulin-dependent diabetes mellitus. J Clin Invest 68:957-969

Received: 30 September 1982

and in revised form: 28 April 1983

Dr. C.J. Bailey

Department of Biological Sciences

University of Aston in Birmingham

Birmingham B4 7ET, UK 